\title{
Seasonal regulation of herbivory and nutrient effects on macroalgal recruitment and succession in a Florida coral reef
}

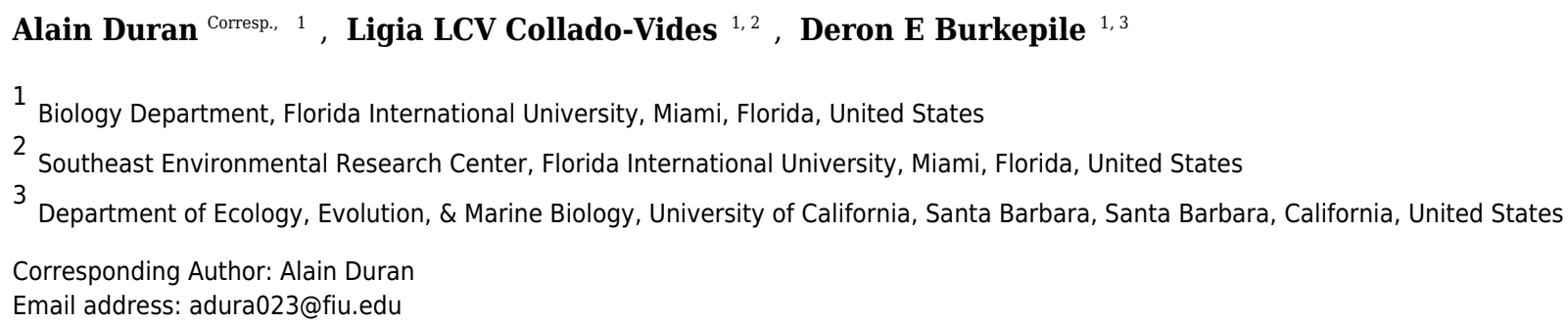

Herbivory and nutrient enrichment are drivers of benthic dynamics of coral reef macroalgae; however, their impact may vary seasonally. In this study we evaluated the effects of herbivore pressure, nutrient availability and potential propagule supply on seasonal recruitment and succession of macroalgal communities on a Florida coral reef. Recruitment tiles, replaced every three months, and succession tiles, kept in the field for nine months, were established in an ongoing factorial nutrient enrichment-herbivore exclusion experiment. The ongoing experiment had already created very different algal communities across the different herbivory and nutrient treatments. We tracked algal recruitment, species richness, and species abundance through time. Our results show seasonal variation in the effect of herbivory and nutrient availability on recruitment of coral reef macroalgae. In the spring, when there was higher macroalgal species richness and abundance of recruits, herbivory appeared to have more control on macroalgal community structure than did nutrients. In contrast, there was no effect of either herbivory or nutrient enrichment on macroalgal communities on recruitment tiles in cooler seasons. The abundance of recruits on tiles was positively correlated with the abundance of algal in the ongoing, established experiment, suggesting that propagule abundance is likely a strong influence on algal recruitment and early succession. Results of the present study suggest that abundant herbivorous fishes control recruitment and succession of macroalgae, particularly in the warm season when macroalgal growth is higher. However, herbivory appears less impactful on algal recruitment and community dynamics in cooler seasons. Ultimately, our data suggest that the timing of coral mortality (e.g. summer vs. winter mortality) and freeing of benthic space may strongly influence the dynamics of algae that colonize open space. [b] 
1 Title. Seasonal regulation of herbivory and nutrient effects on macroalgal recruitment and

2 succession in a Florida coral reef

3

4 Authors: Alain Duran ${ }^{1}$, Ligia Collado-Vides ${ }^{1,2}$ and Deron E. Burkepile ${ }^{1,3}$

5 Affiliation. 1- Biology Department, Florida International University, 11200 S.W. $8^{\text {th }}$ St. Miami.

6 Florida, 33199. 2- Southeast Environmental Research Center, 11200 S.W. $8^{\text {th }}$ St. Miami. Florida,

733199.3 - Department of Ecology, Evolution, \& Marine Biology, University of California,

8 Santa Barbara, Santa Barbara, CA 93106.

9

10 Corresponding author. Name: Alain Duran. Email: adura023@fiu.edu

11

12

13

14

15

16

17

18

19

20

21

22

23 
24 Abstract.

25

26

27

28

29

30

31

32

33

34

35

36

37

Herbivory and nutrient enrichment are drivers of benthic dynamics of coral reef macroalgae; however, their impact may vary seasonally. In this study we evaluated the effects of herbivore pressure, nutrient availability, and potential propagule supply on seasonal recruitment and primary succession of macroalgal communities on a Florida coral reef. Recruitment tiles, replaced every three months, and succession tiles, kept in the field for nine months, were established in an ongoing factorial nutrient enrichment-herbivore exclusion experiment. The ongoing field experiment had already created very different algal communities on the natural reef benthos across the different herbivory and nutrient treatments. We tracked recruitment, species richness, and species abundance of algae through time. Our results show seasonal variation in the effect of herbivory and nutrient availability on recruitment of coral reef macroalgae. In spring, when there was higher macroalgal species richness and abundance of recruits, herbivory appeared to have more control on macroalgal community structure than did nutrients. In contrast, there was no effect of either herbivory or nutrient enrichment on macroalgal communities on recruitment tiles in fall and winter. The abundance of recruits on tiles was positively correlated with the abundance of algae in the ongoing, established experiment, suggesting that propagule abundance is likely a strong influence on algal recruitment and early succession. Results of the present study suggest that abundant herbivorous fishes control recruitment and succession of macroalgae in the warm season (spring and summer) when there is stronger demand of nutrients and macroalgal growth is higher. However, herbivory appears less impactful on algal recruitment and community dynamics in cooler seasons (fall and winter). Ultimately, our data suggest that the dynamics of algae colonizing open space may be 
46 strongly influenced by the timing of coral mortality (e.g. summer vs. winter mortality) and

47 freeing of benthic space.

\section{Introduction}

“Grazing ecosystems" are characterized by an herbivore-based food web where over $50 \%$

of primary production is processed by aquatic or terrestrial grazers (McNauthon, 1985; Douglas

et al., 1998; Burkepile, 2013). Coral reefs are grazing ecosystems where herbivory and nutrient availability are often considered the primary ecological drivers of macroalgal community dynamics (Littler and Littler, 1984; McCook, 1999; Burkepile and Hay, 2006). Field experiments excluding herbivores have resulted in a substantial increase of both biomass and density of some macroalgal species, generating changes in species composition at the community level (Lewis, 1986; Burkepile and Hay, 2009; Ferrari et al., 2012). linked to species-specific responses of macroalgae to nutrient availability (Larned, 1998; Fong et al., 2001; Dailer et al., 2012). In particular, growth rates of some small, fast-growing species quickly peak in nutrient enriched environments (Lapointe et al., 1997; McClanahan et al., 2004; Smith et al., 2005). In contrast, larger slow-growing species, typical of late stages of macroalgal community succession (e.g., Sargassum spp., Amphiroa spp.), often show weak or mixed effects in nutrient enriched areas (McClanahan et al., 2004; Burkepile and Hay, 2009). However, abundance of different macroalgal species can vary seasonally on reefs (Lirman and Biber, 2000;

66 Collado-Vides et al. 2005, 2007), which could explain the variable relative effect of herbivores

67 and nutrients on structuring macroalgal communities (Burkepile and Hay, 2006; Smith et al., 68 2010). 
A number of factors may influence seasonality of algal communities on reefs including

70 seasonal changes in abiotic conditions (e.g. temperature and light; Clifton and Clifton, 1999), the timing and intensity of disturbances (Diaz-Pulido and Garzon-Ferreria, 2000; Diaz-Pulido and McCook, 2004; Goodsell and Connell, 2005) and propagule supply and recruitment (McClanahan 1997; Diaz-Pulido and McCook, 2002, Walters et al., 2002, Vroom et al., 2003). Increases in water temperature and light availability can promote macroalgal growth and trigger reproduction in some species (Clifton 2008; Collado-Vides et al., 2011). For example, both Dictyota pulchella and Sargassum spp. show a peak of abundance during the summer and a loss of biomass in the coolest seasons (Lirman and Biber, 2000; Renken et al., 2010). In contrast, Gracilaria spp. and Stypopodium zonale rather exhibit higher abundance during cooler seasons (Hay and Norris, 1984; Chung et al., 2007). In addition to influencing macroalgal growth rates, temperature also influences the rate of herbivory in fishes with grazing rates often peaking during warmer periods (Ferreira et al., 1998, Smith, 2008; Lefevre and Bellwood, 2010). Thus, variation in abiotic controls of both algal growth rates and rates of herbivory across seasons could result in temporal fluctuations of bottom-up and top-down forcing.

These seasonal differences in macroalgal growth and herbivory rates could affect how disturbances to reefs impact macroalgal community development and succession. For example, in reefs in the Florida Keys, both extreme warm water (Eakin et al., 2010) and cold water (Lirman et al., 2011) anomalies can lead to coral mortality. Given that these disturbances open up free space for macroalgal colonization during different times of the year with different abiotic conditions, different species of algae may become dominant and drive different successional trajectories depending on the timing of these disturbances and the initiation of algal succession. 
91

92

93

94

95

96

97

98

Propagule abundance can also impact community dynamics by influencing the rates of recruitment in marine organisms (Stiger and Payri; 1999; Lotze, Worm and Sommer, 2000; Walters et al 2002; Grorud-Colvert and Sponaugle, 2009). The abundance of adult macroalgal individuals, the number of propagules they produce, and the distance to a suitable substrate for colonization can determine the number of macroalgal recruits in a given area (Kendrick and Walker 1991; Stiger and Payri 1999; Lotze, Worm and Sommer, 2000; Yniguez et al 2015). Thus, abundant adult macroalgae might increase local macroalgal recruitment, especially after relatively localized disturbances such as coral mortality events (Walters et al. 2002, Roff and Mumby, 2012). Consequently, increases in macroalgae due to reductions in herbivory or increases in nutrient availability could lead to increased macroalgal propagule supply and a positive feedback on macroalgal abundance. Yet, no studies have directly addressed how seasonality and propagule supply interact with herbivory and nutrient availability to impact macroalgal community development and succession on coral reefs.

In the current study, we tested how both nutrient availability and herbivory varied across seasons as drivers of recruitment and succession of a coral reef macroalgal community. We used coral limestone tiles as primary substrate in a factorial field experiment, previously established for two years, manipulating access by herbivorous fishes and nutrient availability to examine the effects of herbivory, nutrient enrichment, and macroalgal abundance on algal recruitment patterns and primary succession across seasons. We quantified algal abundance and diversity on both primary substrate and the established macroalgal communities regularly over nine months. We predicted that macroalgal recruitment would be higher in areas with greater adult macroalgal abundance because adult macroalgae act as propagule supply source; and because herbivores consume late successional species, usually large palatable species, herbivory would be the main 
114 driver of macroalgal communities at late successional stages. In addition, we hypothesized that

115 the effect of both nutrient availability and herbivory would be reduced in cooler seasons because

116 lower temperature and less light availability reduce rates of macroalgal growth and at low

117 temperature herbivory rates are typically lower.

118

119 Materials and methods

120 Study site and experimental design

121 This study was conducted from September 2011 to June 2012 on a spur and groove reef

122 system located in the upper Florida Keys near Pickles Reef ( $\left.25^{\circ} 00^{\prime} 05^{\prime \prime} \mathrm{N}, 80^{\circ} 24^{\prime} 55^{\prime \prime} \mathrm{W}\right)$ with the approval of the Florida Keys National Marine Sanctuary (FKNMS-2009-047 and FKNMS-2011-

124 090). The reef is a shallow area $(5-6 \mathrm{~m})$ where parrotfishes and surgeonfishes are the dominant

125 herbivorous fishes and the long-spined urchin, Diadema antillarum, is present at very low

126 densities ( $<1$ individual per $50 \mathrm{~m}^{2}$, authors' pers. obs.). Water temperature oscillates seasonally

127 from $\sim 24^{\circ} \mathrm{C}$ in winter (December and January) to over $30^{\circ} \mathrm{C}$ during summer (Appendix I).

128 In June 2009, eight $9 \mathrm{~m}^{2}$ experimental plots $(3 \times 3 \mathrm{~m})$ were established to examine the

129 interactive effects of herbivory and nutrient availability on benthic community dynamics

130 (Zaneveld et al. 2016). Plots were separated by at least $5 \mathrm{~m}$. Each $9 \mathrm{~m}^{2}$ plot contained two

131 quadrats $\left(1 \times 1 \mathrm{~m}^{2}\right)$ for herbivore exclusion (exclosure), covered with plastic-coated wire mesh

$132\left(2.5 \mathrm{~cm}\right.$ diameter holes) around a $0.5 \mathrm{~m}$ high metal bar frame. Two other quadrats $\left(1 \mathrm{x} 1 \mathrm{~m}^{2}\right)$ were

133 used as herbivore exclusion controls (uncaged) that had metal bar frames with only three sides

134 covered with wire mesh to allow access to all herbivores. As part of the ongoing experiment on

135 the benthos, a third (completely open, no sides or top) control was also used and showed no 
136 differences in algal communities between the exclusion controls and completely open areas

137 (Zaneveld et al., 2016)

138 To mimic nutrient loading, four of the eight $9 \mathrm{~m}^{2}$ experimental plots were enriched with

139 Osmocote (19-6-12, N-P-K) slow-release garden fertilizer. The Osmocote (175g) was placed in 5

$140 \mathrm{~cm}$ diameter PVC tubes with $10(1.5 \mathrm{~cm})$ holes drilled into them. These tubes were wrapped in

141 fine plastic mesh to keep the fertilizer inside and attached to a metal nail within the plot for a

142 total of 25 enrichment tubes spread evenly across each enrichment plot. Enrichment tubes were

143 replaced every 4-6 weeks to ensure continual nutrient addition. The other four $9 \mathrm{~m}^{2}$ plots were

144 kept at ambient nutrient conditions. Yearly sampling of water column nutrients of each

145 experimental plots (Summer 2009, 2010 and 2011) showed that this enrichment increased both

146 dissolved inorganic nitrogen $(3.91 \mu \mathrm{M}$ vs. $1.15 \mu \mathrm{M}$ in enriched vs. ambient) and soluble reactive

147 phosphorus $(0.27 \mu \mathrm{M}$ vs. $0.035 \mu \mathrm{M}$ in enriched vs. ambient) in the water column (for detailed

148 methods see Vega Thurber et al., (2014)). Additionally, nitrogen concentration in the tissues of

149 the common alga Dictyota menstrualis collected from each plot every year (Summer 2009, 2010

150 and 2011) was $20 \%$ higher in the enriched plots compared to the control plots, suggesting that

151 the nutrients from the enrichment were consistently available to benthic organisms (Vega

152 Thurber et al., 2014). The levels of DIN and SRP in the enriched treatment were similar to those

153 reported from other anthropogenic-impacted reefs located around the world (Dinsdale et al.,

154 2008).

155 Ambient nutrient values were obtained from the SERC-FIU Water Quality Monitoring

156 Network, data from this network is open to the public (http://serc.fiu.edu/wqmnetwork/FKNMS-

157 CD/DataDL.htm). Levels of both dissolved inorganic nitrogen (DIN) and soluble reactive

158 phosphorus (SRP) in the ambient nutrient plots were within the range of concentrations for 
159 offshore reefs in the Florida Keys (Boyer \& Briceño, 2010). Water quality data from a nearby

160 reef (Molasses Reef) shows a high variability of nutrient concentration along the years.

161 Particularly, during the study period, ambient levels of DIN (mean $0.58 \mu \mathrm{M}, \max 0.87 \mu \mathrm{M}$ ) and

162 SRP (mean $.038 \mu \mathrm{M}, \max 0.070 \mu \mathrm{M}$ ) were consistently lower than the enrichment treatments

163 (Appendix I). (The highest values of DIN, SRP and temperature were reported for the end of

164 May 2012 and lower values were detected in April 2011 for DIN and December 2011 for SRP,

165 while temperature had its lowest in December 2011 (Appendix 1).

\section{Fish community structure}

To estimate the intensity of herbivore pressure, fish community structure was evaluated

four times during the study period (September, 2011; January, 2012; April, 2012 and July 2012)

using $30 \times 2 \mathrm{~m}$ belt transects $(\mathrm{n}=12)$ placed haphazardly across the study site following AGRRA

included in the AGRRA protocol were identified and size estimated to the nearest $\mathrm{cm}$ by same

diver. Size estimates were converted to biomass for each individual fish using published length:

weight relationships (Bohnsack and Harper, 1988). We did not quantify abundances of the urchin

D. antillarum as they have been rare across the Florida Keys (Chiappone et al., 2002; 2008) and

they have been very infrequently seen at our field site since the establishment of the experiment

176 in 2009 (D. Burkepile pers. obs.).

177

178

179

180

181

\section{Recruitment of macroalgae on primary substrate}

To study macroalgal recruitment across different seasons in the different treatments, we placed two coral limestone settlement tiles $(10 \times 10 \mathrm{~cm}$; cut from quarried South Florida

Pleistocene limestone) in each of the two exclosure and uncaged quadrats within every $9 \mathrm{~m}^{2}$ plot $(n=64$ tiles total) in September 2011. We did not put tiles in completely open areas as data from 
182 the main experiment showed that the macroalgal communities in the uncaged and completely 183 open areas did not differ (Zaneveld et al., 2016). The tiles were attached to plastic mesh with 184 cable ties and anchored to the benthos using $1.9 \mathrm{~cm}$ galvanized staples. These tiles (hereafter 185 'recruitment tiles') were collected after three months and replaced with new tiles to quantify 186 recruitment and early succession during each season. These deployments resulted in a total of 187 three separate sets of data on macroalgal recruitment across different seasons: fall (September188 December 2011), winter (December 2011-March 2012) and spring (March-June, 2012). A 189 tropical storm in summer 2012 removed much of the experimental infrastructure precluding data 190 from the planned summer period.

After three months in the field, recruitment tiles were transported to the laboratory where

192

193

194 195

algae were identified to the lowest possible taxonomic level (Appendix II). Their percent cover was visually quantified using a rule to measure percent cover of each algal individual.

Abundance of each species was classified from 0.1 (single individual $<0.5 \%$ cover), 0.5 (less than three sparse individuals and $<1 \%$ cover), 1 (few individuals and $<5 \%$ cover), and then 5 to 100 with multiples of 5 by the same trained specialist. If a single individual covered $10 \%$ of the tile, then that individual got a $10 \%$ cover. If a single individual was present but below $1 \%$ cover, it was scored as 0.1 or $0.5 \%$ cover depending upon size. The recruitment tiles were then placed in individual separate aquaria to avoid possible propagule contamination. Each tank was prepared to replicate the field conditions as closely as possible (salinity: $35-36$ ppt using artificial seawater, temperature: $25-28^{\circ} \mathrm{C}$, constant water circulation, and artificial high output white light with 12:12 day-night cycle). Initial water was filtered and then the tanks were re-fill with artificial water (Instant ocean) to avoid propagule contamination from the ocean. We kept the tiles in their corresponding aquaria for three months to promote growth of macroalgal recruits 
205 that were unidentifiable in our immediate evaluation due to their small size or lack of identifiable

206 traits. After this period, all macroalgal species were re-identified and any new contribution was

207 added to the species list.

208 Succession of macroalgal communities on primary substrate

209 In September 2011, we also placed a second set of two coral limestone settlement tiles

$210(10 \times 10 \mathrm{~cm})$ (hereafter 'succession tiles') in each exclosure and uncaged quadrat (n=64 tiles total).

211 Succession tiles were kept in the field from September 2011 to June 2012. Macroalgal

212 abundance was visually quantified on succession tiles in situ in January and June 2012 using the

213 same method described above. Macroalgae were identified to the lowest taxonomic level

214 possible and also binned into form-functional groups (FFG) following Steneck and Detheir

215 (1994).

216 Established macroalgal communities

217 Algal abundance of established communities showed significant differences in the

218 benthic macroalgal community composition across the different treatments (Zaneveld et al.

219 2016). These differences in the abundance and community composition of algae could have

220 resulted in differing levels of propagule abundance across treatments, an important factor

221 potentially affecting recruitment and succession on primary substrate in our study. To evaluate

222 the potential propagule supply of each established community, macroalgal abundance was

223 visually quantified within each exclosure and uncaged quadrat in January and June 2012 using

224 the percent cover scale and FFG classification as described above.

225 Statistical analyses

226 Average values of biomass, density and percent cover are followed by calculated

227 standard error. Biomass and density of total and herbivorous fish were compared across seasons 
228 using a one-factor ANOVA. For statistical analyses of the different macroalgal community

229 metrics of recruitment and succession tiles, we averaged data from the two tiles located within

230 each exclosure and uncaged quadrat. For recruitment tiles, succession tiles, and established

231 communities we averaged metrics of the two exclosure quadrats and two uncaged quadrats of

232 each plot such that $\mathrm{n}=4$ for each treatment except for the ambient-exclosure treatment where $\mathrm{n}=3$

233 due to losing exclosures in one plot in May 2012 during a storm.

234 To test for the effects of herbivores, nutrient enrichment, season, and their interactions on

235 algal species richness and overall macroalgal abundance of recruitment tiles, we used a split plot

236 ANOVA with herbivory treatments as subplots nested within nutrient treatment plots, when there

237 were significant treatment $\mathrm{X}$ season interactions, we used split plot ANOVA to assess treatment

238 effects (i.e. nutrient enrichment and herbivore exclosure) within different seasons. Post-hoc

239 analysis Tukey HSD was used to test for differences across season. We used non-metric multi-

240 dimensional scaling (nMDS) and permutational MANOVA (PERMANOVA) to assess the

241 effects of treatments and seasonality on macroalgae community composition of recruitment tiles.

242 We used a similarity percentage analysis (SIMPER) to assess how different species contributed

243 to differences in community structure across treatments. To assess variability in abundance of

244 most common species across treatments and seasons, we used split plot ANOVAs or non-

245 parametric tests when data did not satisfy assumptions for parametric tests.

246 To test the effects of herbivory, nutrient availability, and season on overall algal

247 abundance and the abundance of different FFG, for both successional tiles and established algal

248 communities, we used a split plot ANOVA, with herbivory treatments as subplots nested within

249 nutrient treatment plots. To test the effects of treatment on community succession, a non-metric

250 multi-dimensional scaling (nMDS) and a PERMANOVA were performed on the abundance of 
251 all FFG analyzed seasonally. To examine how macroalgal abundance in the established

252 communities (potential propagule supply) impacted macroalgal recruitment, we used a Pearson

253 correlation to assess the relationship between FFG abundance of established communities and

254 both, succession tiles and recruitment tiles, in both winter and spring. We performed descriptive

255 and inferential analyses using packages Vegan, doBy, MASS and ggplot2 from R program

256 created by R Development Core Team (2012), version 3.2.2.

257

258 Results

259 Fish community structure

260 Overall fish mean biomass and density at the study site were $6495.60 \pm 508.10 \mathrm{~g} / 100 \mathrm{~m}^{2}$

261 (mean $\pm \mathrm{SE}$; data presented as such hereafter) and $39.93 \pm 3.20$ Ind./100m² , respectively.

262 Herbivores (family Scaridae and Acanthuridae) comprised 78\% of overall fish biomass with an

263 average of $5087.17 \pm 569.50 \mathrm{~g} / 100 \mathrm{~m}^{2}$ and $74 \%$ of overall fish density $29.93 \pm 2.10 \mathrm{Ind} . / 100 \mathrm{~m}^{2}$.

264 Total biomass of parrotfish and surgeonfish were $2771.65 \pm 526.60 \mathrm{~g} / 100 \mathrm{~m}^{2}$ and $2315.52 \pm$

$265370.60 \mathrm{~g} / 100 \mathrm{~m}^{2}$, respectively. We saw no temporal changes in biomass or density of total and

266 herbivorous fish as no significant differences were found among seasons (One-factor ANOVA,

$267 p>0.05$ in all cases, Appendix III).

268

269

270

271

272

273

Recruitment of macroalgae on primary substrate (recruitment tiles)

We identified 101 macroalgal taxa (Appendix II) including field and laboratory observations. Macroalgal species richness on recruitment tiles increased across seasons, averaging $9.73 \pm 0.63$ species per tile in fall, $12.13 \pm 0.79$ in winter, and $14.40 \pm 1.19$ in spring (split plot ANOVA, Season, $p=0.003$ ). Neither nutrient enrichment nor herbivore exclosure had an independent or interactive effect on species richness of recruitment tiles (Appendix II). 
274 Overall abundance of macroalgae on recruitment tiles was twofold higher in spring (116.12 \pm

$2759.50 \%)$ compared with fall $(60.00 \pm 7.48 \%)$ and winter $(51.77 \pm 6.31 \%)$ regardless of treatment

276 (Figure 1, split plot ANOVA, Season, $p=0.02$ ). Across seasons the combination of herbivore

277 exclosure and nutrient enrichment had significant impact with noticeable increase in macroalgal

278 abundance compared to other treatments (Figure 1; Appendix III).

279 Macroalgal assemblages on recruitment tiles were different across seasons (nMDS,

280 Figure 2, PERMANOVA, Season: pseudo $\mathrm{F}=7.68, p=0.01)$. Only four groups were present in all

281 seasons (crustose coralline algae (CCA), Cyanobacteria, Jania capillacea and Peyssonnelia spp.)

282 but with dissimilar abundances (Table 1). There was a peak of cyanobacteria in spring while the

283 abundance of Peyssonnelia spp. was four times higher during fall and spring compared to winter

284 (Table 1). Other species such as Ectocarpus sp., Gelidiella sp. and Heterosiphonia sp. increased

285 their abundance in winter although abundance of both Laurencia species peaked in spring (Table

286 1). There was an effect of herbivore exclosure and a significant interaction between herbivore

287 exclosure and season in driving differences in community composition on recruitment tiles

288 (PERMANOVA, Herbivore: pseudo $\mathrm{F}=3.94, p=0.01$ and Herbivory:Season interaction: pseudo

$289 \mathrm{~F}=2.15, p=0.01$, respectively). Analyses within season showed a clear effect of herbivore

290 exclosure and nutrient enrichment in spring which seems to be stronger when both are combined

291 as shown in the nMDS analyses (Figure 2; PERMANOVA, Herbivory: pseudo $\mathrm{F}=6.16, p=0.01$

292 and Nutrient: pseudo $\mathrm{F}=3.08, p=0.04$, respectively).

293 Succession of macroalgae on primary substrate (succession tiles)

294 Excluding herbivores from succession tiles during the study period led to almost double 295 overall macroalgal cover (77.29 $\pm 7.29 \%)$ compared to uncaged tiles $(40.84 \pm 5.22 \%$; split plot

296 ANOVA, Herbivory, $p=0.03$ ), while no other factors showed significant effects (Figure 3; 
297 Appendix II). Filamentous algae increased abundance in spring with $33.83 \pm 4.58 \%$ and was

298 negatively affected by nutrient enrichment (Figure 3, split plot ANOVA, Nutrient, $p=0.05$ ).

299 Herbivory exclusion in ambient nutrient plots increased abundance of filamentous algae in

300 winter while decreased it in spring (Figure 3, split plot ANOVA, Herbivory:Nutrient:Season

301 interaction, $p=0.03$ ). Abundance of foliose macroalgae (e.g. Dictyota spp.) increased when

302 herbivores where excluded (Figure 3; split plot ANOVA, Herbivory, $p=0.03$ ), there was a trend

303 towards nutrient enrichment decreasing foliose macroalgae (Figure 3; split plot ANOVA,

304 Nutrient interaction, $p=0.08$ ). Leathery algae (e.g. Sargassum spp.) increased in June (Figure 3,

305 split plot ANOVA, Season, $p=0.05$ ) and were almost exclusively present in herbivore

306 exclosures, although their abundance was variable and we did not detect any significant

307 statistical effect of exclosures (Figure 3). Articulated calcareous algae (e.g. Jania spp. and

308 Amphiroa spp.) were only present in exclosure treatments (Figure 3) showing a strong effect of

309 herbivore exclusion (the split plot ANOVA did not pick up this signal likely due to all zeros in

310 the uncaged areas). Nutrient enrichment also facilitated articulated calcareous algae with a trend

311 towards higher abundance in nutrient enriched herbivore exclosures (Figure 3, split plot

312 ANOVA, Herbivory:Nutrient interaction, $p=0.06$ ). In both winter and spring, the nMDS analysis

313 showed herbivore exclosure had significant effects on the FFG composition of macroalgal

314 communities (Figure 4, PERMANOVA, Herbivory: pseudo $\mathrm{F}=8.96 ; p=0.01$, pseudo $\mathrm{F}=3.46$,

$315 p=0.03$ respectively). However, there was an effect of nutrient enrichment only in January

316 (Figure 4, PERMANOVA, Nutrient: pseudo $\mathrm{F}=2.84 ; p=0.03$ ).

317 Established macroalgal communities

318 Overall macroalgal abundance of established communities was over twofold higher in

319 spring with $84.3 \pm 7.76 \%$ compared to winter $39.36 \pm 7.55 \%$ (Figure 5, split plot ANOVA, 
320 Season, $p=0.05$ ). Herbivore exclosures had two fold higher algal cover (Figure 5, split plot

321 ANOVA, Herbivory, $p=0.006$ ) than uncaged treatment while there was no effect of nutrient

322 enrichment (Figure 5, Appendix III). Filamentous algae were the only macroalgal group that

323 showed a seasonal increase from winter to spring on established communities (Figure 5, split

324 plot ANOVA, Season, $p=0.04)$. The three groups of upright macroalgae: foliose, leathery and

325 articulated calcareous algae were more abundant in herbivore exclosures (Figure 5). Leathery

326 macroalgae were practically only found in herbivory exclosure treatments regardless of nutrient

327 treatment (Figure 5). Furthermore, articulated calcareous algae (e.g. Jania spp. and Amphiroa

328 spp.) were much more abundant inside exclosures when combined with nutrient enrichment in

329 both winter and spring compared to ambient nutrient levels (Figure 5, split plot ANOVA,

330 Herbivory:Nutrient interaction, $p=0.056)$.

331 There were significant positive correlations of algal abundance of established

332 communities with algal abundance found on recruitment and succession tiles for some algal

333 groups (Table 2). The abundance of leathery macroalgae on established communities was

334 correlated with the corresponding abundances of each treatment found on recruitment tiles in

335 winter (Pearson correlation, $\mathrm{r}=0.97, p=0.03$ ) and with abundance of succession tiles in spring

336 (Pearson correlation, $\mathrm{r}=0.95, p=0.05$ ). Articulated calcareous algae was the only algal group that

337 showed correlations between established communities and corresponding recruitment and

338 succession tiles in both seasons (Table 2).

\section{Discussion}

Here, we show that the impact of herbivory and nutrient availability on recruitment of

342 coral reef algae changes across seasons. We observed an increase in species richness and 
343 abundance of macroalgal recruits towards the warmer (appendix I) season (spring), with recruit

344 abundance noticeably higher when combining reduced herbivory and nutrient enrichment.

345 However, herbivory primarily drove macroalgal abundance and the trajectory of succession over

346 longer time periods, with higher algal abundance for some groups of macroalgae (e.g. articulated

347 calcareous algae) under elevated nutrient conditions. We also found positive correlations

348 between algal abundance in established communities and algal abundance on both recruitment

349 and successional tiles. These data suggest an important role of propagule supply in influencing

350 algal recruitment and succession. Ultimately, the impact of herbivores and nutrient availability

351 on macroalgal recruitment and succession varied across functional groups of algae and seasons,

352 with herbivory the strongest force in warmer seasons while nutrient availability showed the

353 strongest effects in cooler seasons.

354 Macroalgal communities on coral reefs can show noticeable temporal changes in species

355 composition and abundance, associated with abiotic (e.g. temperature, light) and biotic factors

356 (Tsai et al., 2005; Renken et al., 2010; Page-Albins et al., 2012). Some common species in the

357 Caribbean such as Dictyota spp. and Halimeda spp. increase in abundance during summer, often

358 covering over $50 \%$ of the benthos, while others (e.g. turf-forming species) are more abundant

359 during cooler periods of the year (Lirman and Biber, 2000; Renken et al., 2010; Ferrari et al.

360 2012). In our study we found an increase in overall abundance of macroalgal recruits towards

361 spring with distinct species flourishing within treatments. For instance, recruitment of Jania

362 capillacea and Hypnea spinella was higher in spring but mostly within exclosures, which

363 suggests the strong control of herbivory of both species. Both Laurencia cervicornis and $L$.

364 intricata increased in abundance in spring. However, L. cervicornis was abundant in uncaged

365 treatments while L. intricata was abundant in exclosure treatments. Some species of Laurencia 
366 are chemically defended against herbivores (Nagle and Paul, 1998; Pereira, Cavalcanti and

367 Texeira, 2000), which could explain the proliferation of some Laurencia spp. in the presence of

368 herbivores. In contrast, the abundance of small filamentous algal species commonly consumed

369 by herbivorous fish (e.g. Ectocarpus sp., Gelidiella sp. and Heterosiphonia sp.) increased in

370 winter when other studies have shown that grazing rates often decline (Ferreira et al., 1998;

371 Lefevre and Bellwood, 2010). Indeed, we saw an interaction between herbivory and season on

372 community composition suggesting that herbivores have stronger effects on algal recruitment

373 during warmer periods (spring and summer). Since recruitment of corals is often higher during

374 spring and summer (van Woesik et al., 2006), the strong top-down control of algal recruitment

375 during this period could indirectly enhance coral recruitment by freeing space for corals.

376 Herbivory may have been less important in colder seasons due to lower grazing rates combined 377 with lower recruitment rates and slower growth rates of algae.

378 Succession in the absence of herbivores is expected to follow a trajectory characterized

379 by replacement of early, fast growing species (e.g., Enteromorpha sp. Ceramium sp., Felmania

380 sp.) by late successional species such as leathery and calcareous articulated species

381 (McClanahan, 1997). Our results show that nutrient enrichment and herbivore exclosure interact

382 to drive macroalgal succession at early stages (four months), while herbivory appears more

383 important at later stages. After four months, filamentous and foliose algae increased inside

384 exclosures with ambient nutrient levels, while leathery and articulated calcareous flourished in

385 exclosures with nutrient enrichment. After nine months, species considered later successional

386 species (e.g. Sargassum sp. and Amphiroa sp.) were present almost exclusively on succession

387 tiles in exclosures regardless of nutrient enrichment. These results suggest that nutrient

388 availability facilitates the rapid colonization and growth of leathery and articulated calcareous 
389 algae. But, over the long term, herbivory is the primary driver of their abundance. Other studies

390 have shown that nutrient loading does not affect macroalgal species composition at late

391 successional stages but facilitates abundance of early successional species such as turf forming

392 algae and cyanobacteria (McClanahan et al., 2007). In our study we found that both nutrient

393 availability and herbivory are significant drivers at early successional stages, whereas nutrient

394 showed significant effect over later successional stages only when herbivores were excluded.

395 Competition among algae may also be important for determining successional

396 trajectories, especially when herbivory is low. Macroalgal communities on succession tiles

397 within herbivore exclosures were dominated by calcareous articulated and leathery species by the

398 end of the experiment. These species appeared to replace Dictyota spp. and other foliose and

399 filamentous algae, especially under nutrient enrichment, suggesting that these late successional

400 species are better competitors in absence of herbivores. Thus, selective grazing by herbivores on

401 more palatable species (e.g. articulated calcareous) might facilitate the colonization and

402 establishment of less palatable foliose algae. Coral reef herbivores often consume macroalgal

403 species of late successional stages such as leathery (e.g. Sargassum spp. and Turbinaria spp.)

404 and calcareous articulated (e.g. Amphiroa spp., Halimeda spp. and Jania spp.) (Lobel and

405 Ogden, 1981; Burkepile and Hay, 2008; Hoey and Bellwood, 2011), keeping macroalgal

406 communities in stages of early succession. Hixon and Bostroff (1996) found similar results

407 where removal of grazers led to a rapid shift from green and brown filamentous algae to finely

408 branched filaments followed by species forming thicker filaments (e.g. Tolypoicladia

409 glomerulata). Similarly, Thacker et al. (2001) reported a community shift from unpalatable to

410 palatable species of algae when herbivores were excluded from coral reefs on Guam. This

411 pattern is also common in terrestrial ecosystems where selective herbivores target palatable, but 
412 often competitively superior plant species, and release unpalatable species from competition

413 (Briske and Hendrickson, 1998; Torrano and Valderrabano, 2004).

We found that macroalgal abundance on recruitment and succession tiles was correlated

415 with abundance of algae in established communities, which suggests that local propagule supply

416 from the established community may impact early community development. However, we could

417 not conclusively say that recruits were from local sources (i.e. from algae within exclosures) as

418 opposed to from sources from greater distance. In temperate marine communities, particularly

419 for fast-growing species of macroalgae (e.g. Cladophora sp., Polysiphonia sp. and Ceramium

420 sp.), propagule abundance has been proposed as one of the main drivers of macroalgal

421 population growth (Worm and Lotze, 2006; Karez et al., 2004). However, further studies are

422 needed to evaluate spatial and temporal variation of algal propagule supply and subsequent algal

423 settlement in relation to herbivory and nutrient levels. For instance, since herbivores feed on

424 adult macroalgae as well as recruits they might be controlling algal recruitment and abundance at

425 multiple stages of the algal life cycle. Further, different species of herbivores could be important

426 for controlling the same algal species at different life stages as some herbivorous fishes tend to

427 focus more on early successional algae and would be more likely to consumer algal recruits

428 while other herbivorous species focus on late-successional algae (Burkepile and Hay, 2010).

429 The combined effects of herbivore exclosure and nutrient enrichment showed strong

430 effects on abundance of macroalgae on recruitment tiles, particularly during the warmer seasons.

431 This result suggests that reefs that are both overfished (low herbivorous fish biomass) and have

432 high nutrient loading will have higher recruitment of algae during spring and summer. These

433 higher recruitment rates may mean that these reefs are more likely to undergo regime shifts or

434 state changes to communities with abundant algae when corals die. The impacts could be 
435

436

437

438

439

440

441

442

443

444

445

446

447

448

449

450

451

452

453

454

455

456 magnified if coral mortality occurs primarily in warmer seasons when herbivorous fishes are the most important for impacting algal recruitment. It is expected that bleaching events caused by increasing water temperature in the Florida Keys will increase in intensity and frequency (Manzello, 2015). Severely bleached corals can be quickly colonized by algae (Diaz-Pulido and McCook, 2002) that once settled can used existing higher nutrient availability to growth and develop. Thus, protecting herbivores is crucial to facilitate control of macroalgal recruits that can settle on recently dead corals during these summer events. In addition, warmer seasons of the Florida Keys coincide with increases in both DIN and SRP (Appendix I) which might exacerbate the impact of other ecological stressors during warmest seasons (Vega et al., 2014). Increases of nitrogen and phosphorus can enhance growth rate of algae and consequently facilitate algal dominance in low herbivory reef. Thus, overfished reef can quickly undergo algal succession with rapid dominance of foliose and filamentous algae, overfished and nutrient enriched reefs can rapidly increase abundance of leathery and articulated calcareous algae when space is available. While filamentous and foliose algae can reduce coral recruitment and harm small adult colonies, leathery and articulated calcareous algae can in addition shade and physically harm colonies by abrasion (McCook et al., 2001). Thus, overfishing herbivores and nutrient pollution can have strong impact on algal succession and, ultimately, their interactions with corals.

\section{Acknowledgements}

Many thanks to all those that helped keep the exclosure experiment running: A. Shantz, C. Pritchard, R. Welsh, M. Ladd. Thanks to Dr. Deni Rodriguez and Dr. Elizabeth Lacey for their advising during the macroalgae identification process and motivating scientific discussion. 
457 We also thank the journal reviewers and editor for their accurate comments that facilitated the

458 quality improvement of the original work.

459

460

461

462

463

464

465

466

467

468

469

470

471

472

473

474

475

476

477

478

479

480

481

482

483

484

485

486

487

488

489

490

491

492

493

494

495

496

497

\section{References}

Bohnsack JA and Harper DE. 1988. Length-weight relationships of selected marine reef fishes from southeastern United States and the Caribbean. NOAA Tech. Mem. NMFS-SEFC215. $31 \mathrm{p}$.

Boyer JN and Briceño HO. 2010. Annual report of the water quality monitoring project for the water quality protection program of the Florida Jeys National Marine Sanctuary. Southeast Environmental Research Center, Florida International University, Miami, FL.

Briske DD and Hendrickson JR. 1998. Does selective defoliation mediate competitive interactions in a semiarid savannah? A demographic evaluation. Journal of vegetation Science, 9: 611-622.

Burkepile DE and Hay ME. 2006. Herbivore VS nutrient control of marine primary producers: context-dependent effects. Ecology, 87(12):3128-3139.

Burkepile DE and Hay ME. 2008. Herbivore species richness and feeding complementary affect community structure and function on a coral reef. Proceedings of the National Academy of Science, 105 (42): 16201-16206.

Burkepile DE and Hay ME. 2009. Nutrient versus herbivore control of macroalgal community development and coral growth on a Caribbean reef. Marine Ecology Progress Series, 389: 71-84.

Burkepile DE and Hay ME. 2010. Impact of herbivore identity on algal succession and coral growth on a Caribbean Reef. PLoS ONE, 5(1):e8963.doi:10.1371/journal.pone.0008963.

Burkepile DE. 2013. Comparing aquatic and terrestrial grazing ecosystems: is the grass really greener? Oikos, 122: 306-312.

Chiappone M, Rutten LM, Swanson DW and Miller SL. 2008. Population status of the sea urchin Diadema antillarum in the Florida Keys 25 years after the Caribean mass mortlity. Proceeding of the $11^{\text {th }}$ Interantional Coral Reef Symposium, Ft. Lauderdale. Florida, 711, 2008. Section number 18.

Chiappone M, Swanson DW and Miller SL. 2002. Density, spatial distribution and size structure of sea urchins in Florida Keys coral reef and hard-bottom habitats. Marine Ecology Progress Series, 235: 117-126.

Chung C, Hwang R-L, Lin S-H, Wu T-M, Wu J-Y, Su S-W Chen C-S and Lee T-M. 2007. Nutrient, temperature and salinity as primary factors influencing the temporal dynamics of macroalgal abundance and assemblage structure on a reef of Lang Bay in Taitung in southeastern Taiwan. Botanical Studies, 48: 419-433.

Clifton KE and Clifton LM. 1999. The phenology of sexual reproduction by green algae (Bryopsidales) on Caribbean coral reefs. J. Phycol, 35: 24-34.

Clifton KE. 2008. Spatial patterns of reproductive synchrony by four genera of tropical green seaweed across a latitudinal gradient in the Caribbean. Proceedings of the $11^{\text {th }}$ International Coral Reef Symposium, Ft. Lauderdale, Florida, 7-11 July: 351-355. 
498

499

500

501

502

503

504

505

506

507

508

509

510

511

512

513

514

515

516

517

518

519

520

521

522

523

524

525

526

527

528

529

530

531

532

533

534

535

536

537

538

539

540

541

Collado-Vides L, Caccia V, Boyer JN, and Fourqurean JW. 2007. Spatiotemporal distribution of macroalgal groups in relation to water quality in the Florida Keys National Marine Sanctuary. Estuarine, Coastal and Shelf Sciences, 73: 680-694.

Collado-Vides L, Mazzei V, Thyberg T and Lirman D. 2011. Spatio-temporal patterns and nutrients status of macroalgae in a heavily managed region of Biscayne Bay, Florida, USA. Botanica Marine, 54: 377-390.

Collado-Vides L, Rutten LM and Fourqurean JW. 2005. Spatiotemporal variation of the abundance of calcareous green macroalgae in the Florida Keys: A study of synchrony within a macroalgal functional-form group. Journal Phycology, 41:742-752.

Dailer ML, Smith JE and Smith CM. 2012. Responses of bloom forming and non-bloom forming macroalgae to nutrient enrichment in Hawai'I, USA. Harmful Algae, 17: 111-125.

Diaz-Pulido G and Garzon-Ferreira J. 2002. Seasonality in algal assemblages on Upwellinginfluenced coral reefs in the Colombian Caribbean. Botanica Marina. 45: 884-292.

Diaz-Pulido G and McCook LJ. 2002. The fate of bleached corals patterns and dynamics of algal recruitment. Marine Ecology Progress Series, 232: 115-128.

Diaz-Pulido G and McCook LJ. 2004. Effects of live coral, epipithic algal communities and substrate type on algal recruitment. Coral Reefs, 23: 225-233.

Dinsdale EA, Pantos O, Smriga S, . Edwards RA, Angly F, Wegley L, Hatay M, Hall D, Brown E, Haynes M, Krause L, Salas E, Sandin SA., Thurber RV, Willis BL, Azam F, Knowlton $\mathrm{N}$ and Rohwer F 2008. Microbial ecology of four coral atolls in the northen line islands. PLoS ONE, 3(2): e1584. doi:10.1371/journal.pone.0001584.

Douglas AF, McNaughton SJ and Tracy BF. 1998. The ecology of the Earth's grazing ecosystems. BioScience, 48 (7): 513-521.

Eakin CM, Morgan JA, Heron SF, Smith TB, Liu G, Alvarez-Filip L, Baca B, Bartels CB, Bouchon C, Brandt M, Bruckner AW, Bunkley-Williams L, Cameron A, Causey BD, Chiappone M, Christensen TRL, Crabbe MJC, Day O, de la Guardia E, Diaz-Pulido G, Diresta D, Gil-Agudelo D, Gilliam DS, Ginsburg RN, Gore S, Guzman HM, Hendee JC, Hernadez-Delgado EA, Husain E, Jeffrey CFG, Jones RJ, Jordan-Dahlgren E, Kaufman LS, Kline DI, Kramer PA, Lang JC, Lirman D, Mallela J, Manfrino C, Marechal J-P, Marks K, Mihaly, Miller WJ, Mueller EM, Mueller EM, Toro CAO, Oxenford HA, Ponce-Taylor, Quinn N, Ritchie KB, Rodriguez S, Ramirez AR, Romano S, Samhouri JF, Sanchez JA, Schmahl GP, Shank BV, Skirving WJ, Sasha CCS, Villamizar E, Walsh SM, Walter C, Weil E, Williams EH, Woody K and Yusuf R.Y. 2010.Caribbean Corals in Crisis: Record Thermal Stress, Bleaching, and Mortality in 2005. PLoS ONE, 5(11): e13969. doi:10.1371/journal.pone.0013969.

Ferreira CEL, Peret AC, Coutinho R. 1998. Seasonal grazing rates and food processing by tropical herbivorous fishes. Journal of Fish Biology, 53: 222-235.

Ferrari R, Gonzalez-Rivero M, Ortiz JC and Mumby PJ. 2012. Interaction of herbivory and seasonality on the dynamics of Caribbean macroalgae. Coral Reefs, 31 (3): 683-692.

Ferreira CEL, Peret AC and Coutinho R. Seasonal grazing rates and food processing by tropical herbivorous fishes. Journal of Fish Biology, 53 (A): 222-235.

Fong P, Kramer K, Boyer KE and Boyle KA. 2001. Nutrient content of macroalgae with differeing morphologies may indicate sources of nutrients for tropical marine systems. Marine Ecology Progress Series, 220: 137-152. 
542 Goodsell PJ and Connell SD. 2005. Disturbance initiates diversity in recruitment of canopy-

543 forming algae: interactive effects of canopy-thinning and substrate availability.

$544 \quad$ Phycologia, 44 (6): 632-639.

545 Grorud-Colvert K and Sponaugle S. 2009. Larval supply and juvenile recruitment of coral reef

546 fishes to marine reserves and non-reserves of upper Florida keys, USA. Marine Biology,

$547 \quad 156: 277-288$.

548 Hay ME and Norris JN. 1984. Seasonal reproduction and abundance of six sympatric species of

549

550

551

552

553

554

555

556

557

558

559

560

561

562

563

564

565 Gracilaria Grev. (Gracilariaceae; Rodhophyta) on a Caribbean subtidal sand plain. Hydrobiologia, 116/117: 63-94.

Hixon MA and Brostoff WN. 1996. Succession and herbivory: effects of differential fish grazing on Hawaiian coral-reef algae. Ecological Monographs,66(1): 67-90.

Hoey AS and Bellwood DR. 2011. Suppression of herbivory by macroalgal density. A critical feedback on coral reefs? Ecology Letters, $14: 267-273$.

Kares R, Engelbert S, Kraufvelin P, Pedersen MF and Sommer U. 2004. Biomass response and change in composition of ephemeral macroalgal assemblages along an experiemental gradient of nutrient enrichment. Aquatic Botany, 78: 103-117.

Kendrick GA and Walker DI 1991. Dispersal distances of Sargassum spinuligerum (Sargassaceae, Phaeophyta) measured directly by vital staining and venturisuction sampling. Marine Ecology Progress Series, 79: 133-138.

Lang C J, Marks KW, Kramer PA, Kramer PR and Ginsburg R N. 2010. AGRRA protocols version 5.4 in: http://www.agrra.org/method/AGRRA-V5.4_2010.

Lapointe BE, Littler MM and Littler DS. 1997. Macroalgal overgrowth of fringing coral reefs at discovery bay, Jamaica: Bottom-up versus Top-down control. Procceding of $8^{\text {th }}$ Int. Coral Reef Symposium, 1: 927-932.

Larned ST. 1998. Nitrogen versus phosphorus limited growth and sources of nutrients for coral reef macroalgae. Marine Biology, 132: 409-421.

Lefevre CD and Bellwood DR. 2010. Seasonality in coral reef algae: variation in condition and susceptibility to herbivory. Marine Biology, 157: 955-965.

Lewis SM. 1986. The role of herbivorous fishes in the organization of the Caribbean reef community. Ecological Monographs, 56 (3): 183-200.

Lirman D and Biber P. 2000. Seasonal dynamics of macroalgal communities of the Northern Florida Reef Track. Botanica Marina, 43: 305-314.

Lirman D, Schopmeyer S, Manzello D, Gramer LJ, Precht WF, Muller-Karger F, Banks K, Barnes E, Bartels B, Bourque A, Byrne J, Donahue S, Duquesnel J, Fisher L, Gilliam D, Hendee J, Jonhson M, Maxwell K, McDevitt E, Monty J, Rueda D, Ruzicka R and Thanner S.2011. Severe 2010 Cold-Water Event Caused Unprecedented Mortality to Corals of the Florida Reef Tract and Reversed Previous Survivorship Patterns. PLoS ONE, 6(8): e23047. doi:10.1371/journal.pone.0023047

Littler MM and Littler DS. 1984. Models of tropical reef biogenesis: the contribution of algae. Progress in Phycological research, 3: 323-364.

Lobel PS and Ogden JC. 1981. Foraging by the herbivorous parrotfish Sparisoma radians. Marine Biology, 64: 173-183.

Lotze H. K., B. Worm and U. Sommer. 2000. Propagule banks, herbivory and nutrient supply control population a development and dominance patterns in macroalgal blooms. Oikos, 89: 46-58. 
587

588

589

590

591

592

593

594

595

596

597

598

599

600

601

602

603

604

605

606

607

608

609

610

611

612

613

614

615

616

617

618

619

620

621

622

623

624

625

626

627

628

629

630

Manzello DP. 2015. Rapid recent warming of coral reef in the Florida Keys. Scientific Reports 5: 16762, Doi: 10.1038/srep16762.

McClanahan TR, Carreiro-Silva M and DiLorenzo M. 2007. Effect of nitrogen, phosphorous, and their interaction on coral reef algal succession in Glover's Reef, Belize. Marine Pollution Bulletin, 54: 1947-1957.

McClanahan TR, Sala E, Mumby PJ and Jones S. 2004. Phosphorus and nitrogen enrichment do not enhance brown frondose "macroalgae". Marine Pollution Bulletin, 48: 196-199.

McClanahan TR. 1997. Primary succession of coral reef algae: differing patterns on fished versus unfished reefs. Journal of experimental marine biology and ecology, 218: 77-102.

McCook L. J., J. Jompa and G. Diaz-Pulido. 2001. Competition between coral and algae on coral reefs: a review of evidences and mechanisms. Coral Reefs, 19: 400-417.

McCook LJ. 1999. Macroalgae, nutrients and phase shifts on coral reef: scientific issues and management consequences for the Great Barrier Reef. Coral Reef, 18: 357-367.

McNauthon SJ. 1985. Ecology of a grazing ecosystem: The Serengeti. Ecological Monographs, 55 (3): 260-294.

Mumby PJ and Steneck RS. 2008. Coral reef management and conservation in light of rapidly evolving ecological paradigms. Trends in Ecology and Evolution, 23 (10): 555-563.

Mumby PJ, Foster NL and Glynn EA. 2005. Patch dynamics of coral reef macroalgae under chronic and acute disturbance. Coral Reefs, 24: 681-692.

Nagle DG and Paul VLJ. 1998. Chemical defense of a marine cyanobacterial bloom. Journal of Experiment Marine Biology and Ecology, 225: 29-38.

Page-Albins KPSV, Hoeke R, Albins MA and Smith CM. 2012. Patterns in benthic coral reef communities at Pearl and Hermes Atoll along a wave exposure gradient. Pacific Science, $66(4): 1-32$.

Pereira, RC, Cavalcanti DN and Texeira VL. 2000. Effects of secondary metabolites from the tropical brown alga Dictytoa menstrualis on the amphipods Parhyale hawaiensis. Marine Ecology Progress Series, 205: 95-100.

R Development Core Team (2012). R: A language and environment for statistical computing. R Foundation for Statistical Computing,Vienna, Austria. ISBN 3-900051-07-0, URL http://www.R-project.org.

Renken H, Mumby PJ, Matsikis I and Edwards HJ. 2010. Effects of physical environments conditions on the path dynamics of Dictyota pulchella and Lobophora variegata on the Caribbean coral reefs. Marine Ecology Progress Series, 403: 63-74.

Roff G and Mumby P J. 2012. Global disparity in the resilience of coral reefs. Trens in Ecology and Evolution, 27(7): 404-413.

Smith JE, Hunter C and Smith CM. 2010. The effects of top-down versus bottom-up control on benthic coral reef community structure. Oecologia, 163:497-507.

Smith JE, Runcie JW and Smith CM. 2005. Characterization of a large-scale ephemeral bloom of the green alga Cladophora sericea on coral reefs of West Maui, Hawai. Marine Ecology Progress Series, 302: 77-91.

Smith TB. 2008. Temperature effects on herbivory for an Indo-Pacific parrotfish in Panama: Implications for coral-algal competition. Coral Reefs, 27: 397-405.

Steneck RS and Dethier MN. 1994. A functional group approach to the structure of algaldominated communities. Oikos, 69: 476-498. 
631

632

633

634

635

636

637

638

639

640

641

642

643

644

645

646

647

648

649

650

651

652

653

654

655

656

657

658

659

660

661

662

663

664

665

Stiger V and Payri CE. 1999. Spatial and temporal patterns of settlement of the brown macroalgae Turbinaria turbinata and Sargassum mangarevense in a coral reef on Tahiti. Marine Ecology Progress Series, 191: 91-100.

Thacker RW, Ginsburg DW and Paul VJ.. 2001. Effects of herbivores exclusion and nutrient enrichment on coral reef macroalgae and cyanobacteria. Coral Reefs, 19: 318-329.

Torrano L and Valderrabano J. 2004. Review. Impact of grazing on plant communities in forestry areas. Spanish Journal of Agricultural Research, 2(1): 93-105.

Tsai C-C, Chang J-S, Sheu F, Shyu Y-T, Yi-Chuan A, Wong S-L, Dai C-F and Lee T-S. 2005. Seasonal growth dynamics of Laurencia papillosa and Gracilaria coronifolia from a highly eutrophic reef in southern Taiwan: temperature limitation and nutrient availability. Journal of Experimental Marine Biology and Ecology, 315: 49-69.

Van woesik R, Lacharmoise F and Koksal S. 2006. Annual cycles of solar insolation prdict spawning times of Caribbean corals. Ecology Letters, 9: 390-398. Doi: 10.1111/j.14610248.2006.00886.x.

Vega-Thurber RL,. Burkepile DE., Fuchs C, Shantz AA, Mcminds R and Zaneveld JR. 2014. Chronic nutrient enrichment increases prevalence and severity of coral disease and bleaching. Global Change Biology, Doi: 10.1111/gcb.12450.

Vroom PS, Smith CM, Coyer JA, Walters LJ, Hunter CL, Beach KS and Smith JE. 2003. Field biology of Halimeda tuna (Bryopsidales, chlorophyta) across a depth gradient: comparative growth, survivorship, recruitment, and reproduction. Hydrobiologia, 501:149-66.

Walters LJ, Smith CM, Coyer JA, Hunter CL, Beach KS and Vroom PS. 2002. Asexual propagation in the coral reef macroalgae Halimeda (Chlorophyta, Bryopsidales): production, dispersal and attachment of small fragments. J. Exp. Mar. Biol. Ecol, 278:4765.

Worm B and Lotze HK. 2006. Effects of eutrophication, grazing, and algal blooms on rockery shores. Limnology. Oceanography, 51 (1, part 2): 569-579.

Yñiguez AT, McManus JW and Collado-Vides L. 2015 Consequences of morphological plasticity and fragmentation on space occupation of coral reef macroalgae. Ecological Modelling, 309-310: 128-142.

Zaneveld, JR, Burkepile DE, Shantz AA, Catharine EP, McMinds R, Payet JP, Welsh R, Correo AMS, Lemoine NP, Rosales S, Fuchs C and Vega-Thurber R. 2016. Overfishing, pollution, and thermal stress interact to disrupt coral reefs to microbial scales. Nature Communications, Doi, 10.1038/ncomms11833. 
Table 1. Abundance of dominant macroalgal taxa found on recruitment tiles per season. Statistics column refers to analysis performed to compare abundance of specific taxa across season ( $\mathrm{F}$ and $p$ from one-factor ANOVA and N/A and $p$ from Friedman test). Different letters indicate post hoc analysis (SNK or Wilcoxon pair analysis) when abundance differed across seasons.

\begin{tabular}{|c|c|c|c|c|c|}
\hline \multirow{2}{*}{ Species } & \multirow{2}{*}{$\begin{array}{c}\begin{array}{c}\text { Fall } \\
\text { (Sep-Dec) }\end{array} \\
\begin{array}{c}\text { Percent cover } \\
(\%)\end{array} \\
\end{array}$} & \multirow{2}{*}{$\begin{array}{c}\begin{array}{c}\text { Winter } \\
\text { (Jan-Mar) }\end{array} \\
\text { Percent cover } \\
(\%)\end{array}$} & \multirow{2}{*}{$\begin{array}{c}\text { Spring } \\
\text { (Mar-Jun) } \\
\text { Percent cover } \\
(\%) \\
\end{array}$} & \multicolumn{2}{|c|}{$\begin{array}{l}\text { Statistical } \\
\text { sign. }\end{array}$} \\
\hline & & & & $\mathbf{F}$ & $p$ \\
\hline Peyssonnelia sp. & $12.28(\mathrm{~A})$ & 3.43 (B) & $12.36(\mathrm{~A})$ & 11.405 & .001 \\
\hline $\begin{array}{l}\text { Crustose coralline } \\
\text { algae (CCA) }\end{array}$ & 11.24 & 7.41 & 6.40 & 2.157 & .124 \\
\hline Jania capillacea & 4.68 & 2.20 & 10.44 & N/A & .173 \\
\hline Neosiphonia howei & $3.90(\mathrm{~A})$ & $0.00(\mathrm{~B})$ & $2.86(\mathrm{~A})$ & $\mathrm{N} / \mathrm{A}$ & .001 \\
\hline Cyanobacteria & $6.6(\mathrm{~B})$ & $3.56(\mathrm{~B})$ & $37.84(\mathrm{~A})$ & $\mathrm{N} / \mathrm{A}$ & .001 \\
\hline Heterosiphonia sp. & $0.00(\mathrm{~B})$ & $1.27(\mathrm{~A})$ & $0.00(\mathrm{~B})$ & $\mathrm{N} / \mathrm{A}$ & .001 \\
\hline Ectocarpus sp. & $0.00(\mathrm{~B})$ & $12.20(\mathrm{~A})$ & $0.00(\mathrm{~B})$ & $\mathrm{N} / \mathrm{A}$ & .001 \\
\hline $\begin{array}{l}\text { Laurencia } \\
\text { cervicornis }\end{array}$ & $2.28(\mathrm{~B})$ & $0.33(\mathrm{~B})$ & $6.48(\mathrm{~A})$ & N/A & .001 \\
\hline Hypnea spinella & $1.56(\mathrm{~A})$ & $0.82(\mathrm{~A})$ & $4.30(\mathrm{~B})$ & $\mathrm{N} / \mathrm{A}$ & .001 \\
\hline Gelidiella sp. & $0.00(\mathrm{~B})$ & $1.16(\mathrm{~A})$ & $0.00(\mathrm{~B})$ & N/A & .001 \\
\hline Laurencia intricata & $0.00(\mathrm{~A})$ & $0.00(\mathrm{~A})$ & $3.42(\mathrm{~B})$ & $\mathrm{N} / \mathrm{A}$ & .001 \\
\hline
\end{tabular}

671

672

673

674

675

676

677

678

679

680

681

682

683

684

685 
686

687

688

689

690

Table 2. Pearson correlation between algal form functional group (FFG) abundance on recruitment or succession tiles and abundance of algal FFG in established communities for winter and spring. Bolded values show significant effects.

\begin{tabular}{|c|c|c|c|c|c|}
\hline \multirow{2}{*}{ Season } & \multirow{2}{*}{ FFG } & \multicolumn{2}{|c|}{ Recruitment tiles } & \multicolumn{2}{|c|}{ Succession tiles } \\
\hline & & Coef. Corr (r) & $p$ & Coef. Corr (r) & $p$ \\
\hline \multirow{6}{*}{$\begin{array}{c}\text { Winter } \\
\text { (January) }\end{array}$} & Overall & 0.59 & 0.002 & 0.86 & 0.001 \\
\hline & Filamentous & 0.89 & 0.11 & 0.35 & 0.65 \\
\hline & Foliose & 0.49 & 0.51 & 0.44 & 0.56 \\
\hline & Leathery & 0.97 & 0.03 & 0.28 & 0.72 \\
\hline & Articulated-Calcareous & 1.00 & 0.004 & 0.99 & 0.01 \\
\hline & Crustose & -0.94 & 0.04 & -0.77 & 0.23 \\
\hline \multirow{6}{*}{$\begin{array}{l}\text { Spring } \\
\text { (June) }\end{array}$} & Overall & 0.53 & 0.01 & 0.43 & 0.03 \\
\hline & Filamentous & -0.33 & 0.67 & -0.51 & 0.49 \\
\hline & Foliose & -0.09 & 0.91 & $\mathrm{~N} / \mathrm{S}$ & $\mathrm{N} / \mathrm{S}$ \\
\hline & Leathery & 0.88 & 0.12 & 0.95 & 0.05 \\
\hline & Articulated-Calcareous & 0.95 & 0.05 & 1.00 & 0.01 \\
\hline & Crustose & 0.47 & 0.53 & 0.12 & 0.88 \\
\hline
\end{tabular}

691

692

693

694

695

696

697

698

699

700

701

702

703

704

705

706

707

708 


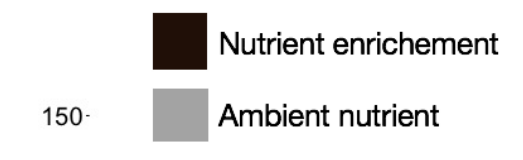

Herbivores $p=0.31$

Nutrients $p=0.18$

Season $\boldsymbol{p}=\mathbf{0 . 0 2}$

Herbivores:Nutrient $p=0.12$

Herbivores:Nutrient:Season $p=0.23$

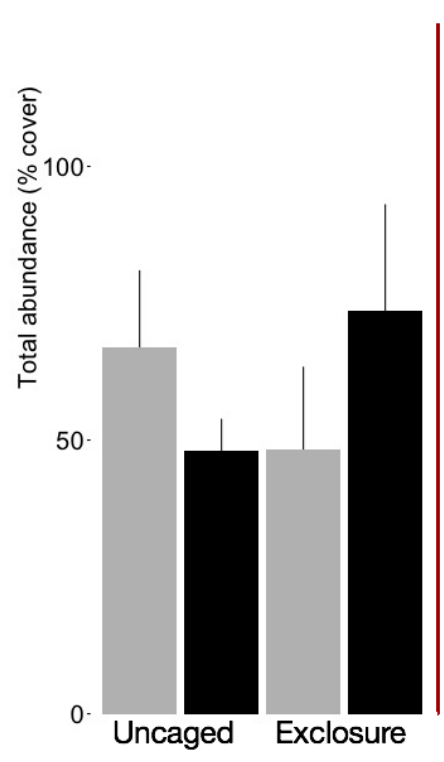

Fall

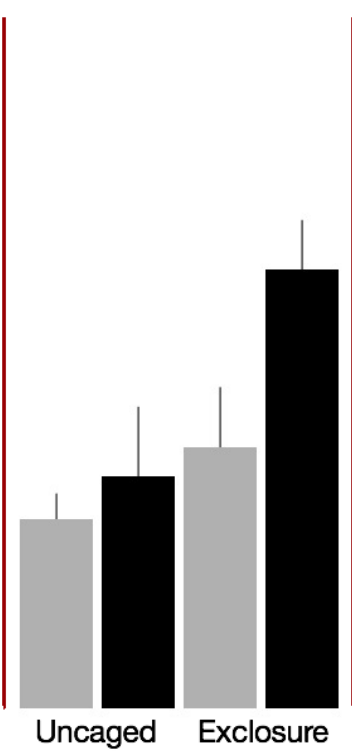

Winter

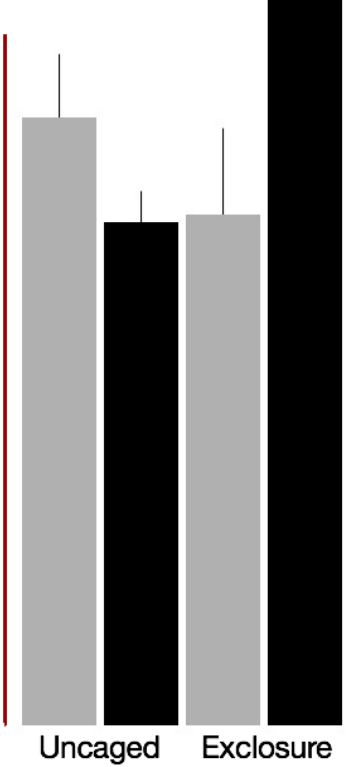

Spring

Figure 1. Overall abundance of macroalgae on recruitment tiles by treatments within each season. Bars represent means \pm SEM. Probability values $(p)$ come from Split plot ANOVA of main treatment effects. Red lines help to distinguish bars across seasons. With left side for fall and right side for spring 


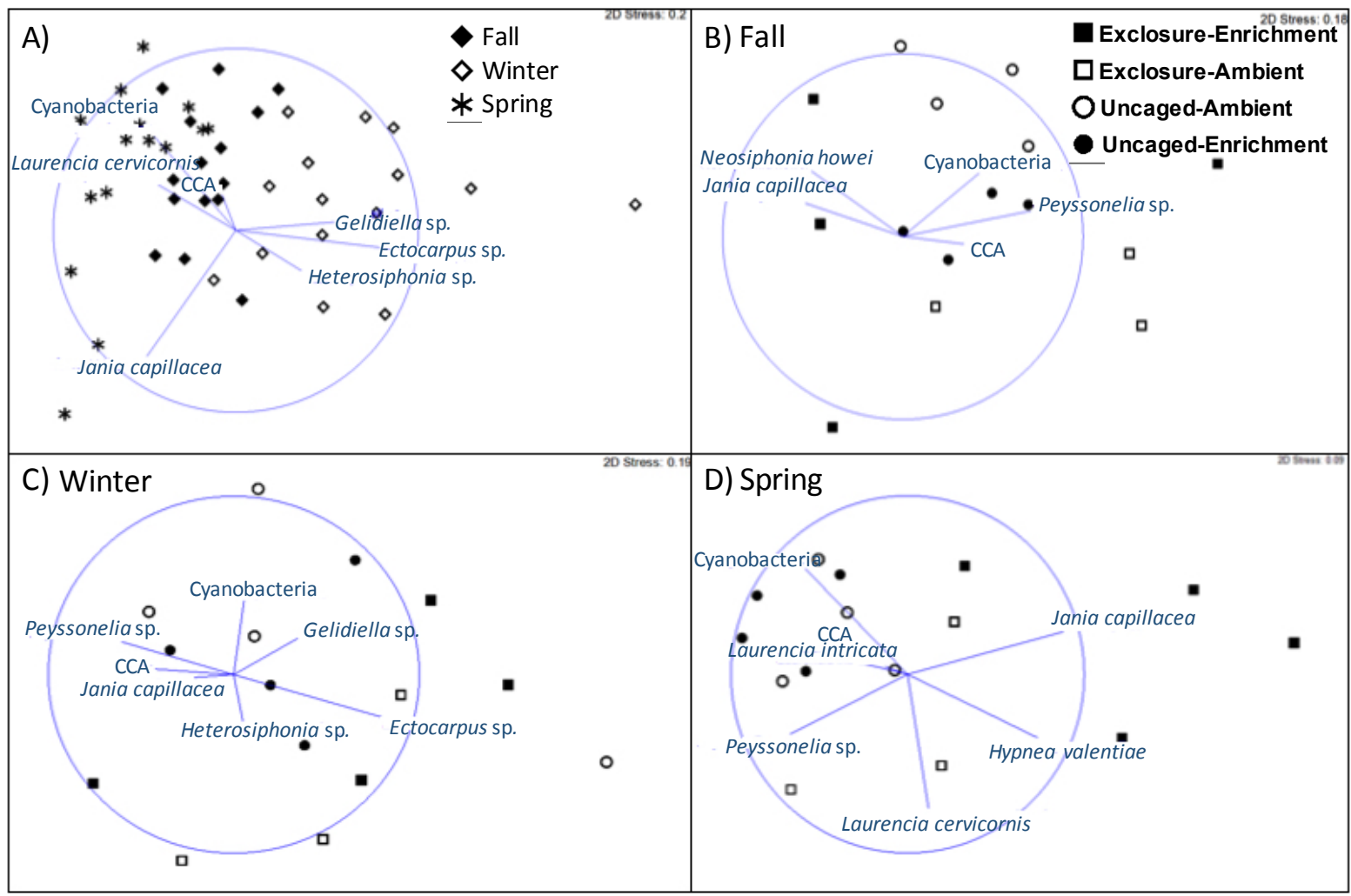

719

720

721

722

723

724 Figure 2. Non-metric Multidimensional Scaling analysis of algal abundance in communities on recruitment tiles across seasons (A) and in each treatment by season (B-D).

726

727

728

729

730 


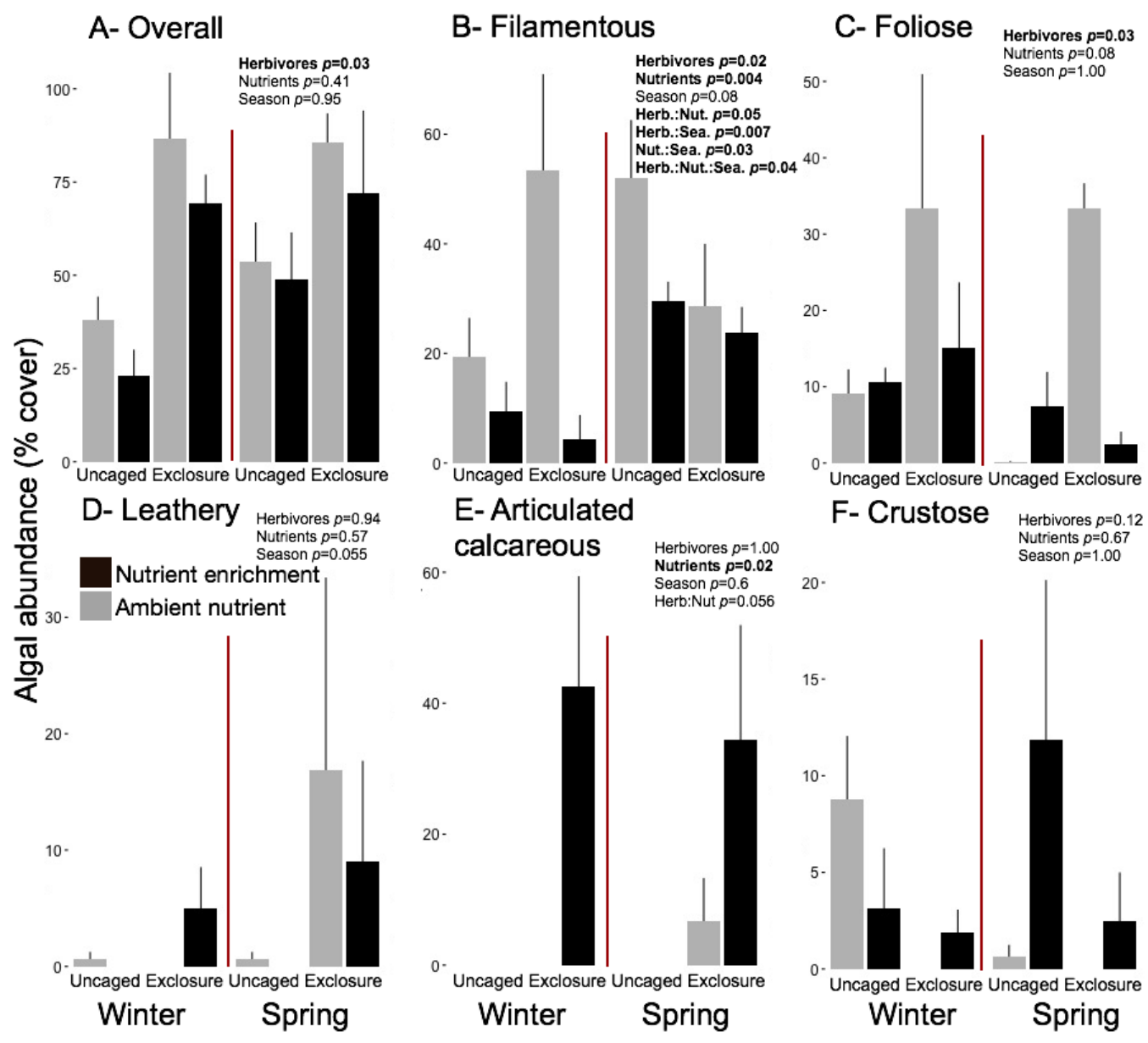

Figure 3. Abundance of macroalgal FFG on succession tiles by treatment in Winter (January) and Spring (June). Bars represent means \pm SEM. Probability values $(p)$ come from Split plot ANOVA for main treatment effects and significant interactions. Red lines help to distinguish bars across seasons with right side for spring and left side winter. 


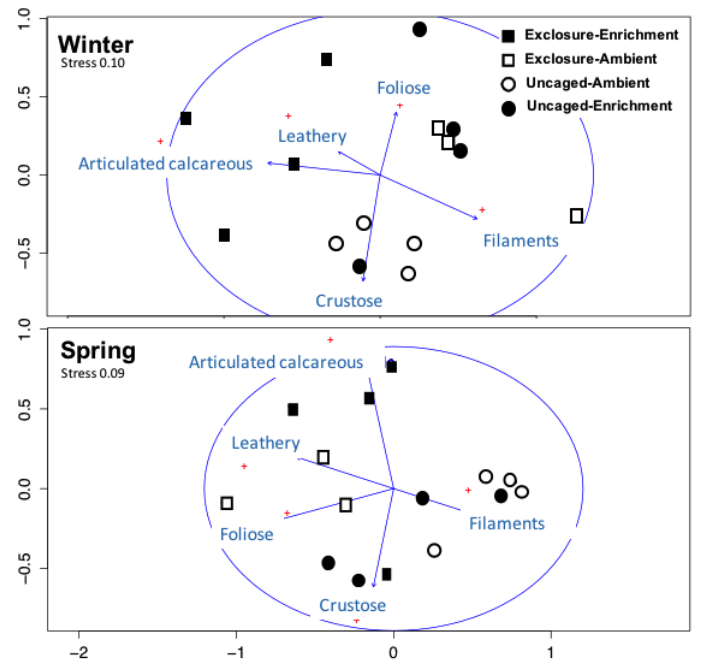

749 Figure 4. Non-metric Multidimensional Scaling analysis of algal cover on successional tiles

750 using percent cover of form-functional groups among treatments in winter and spring.

751

752 

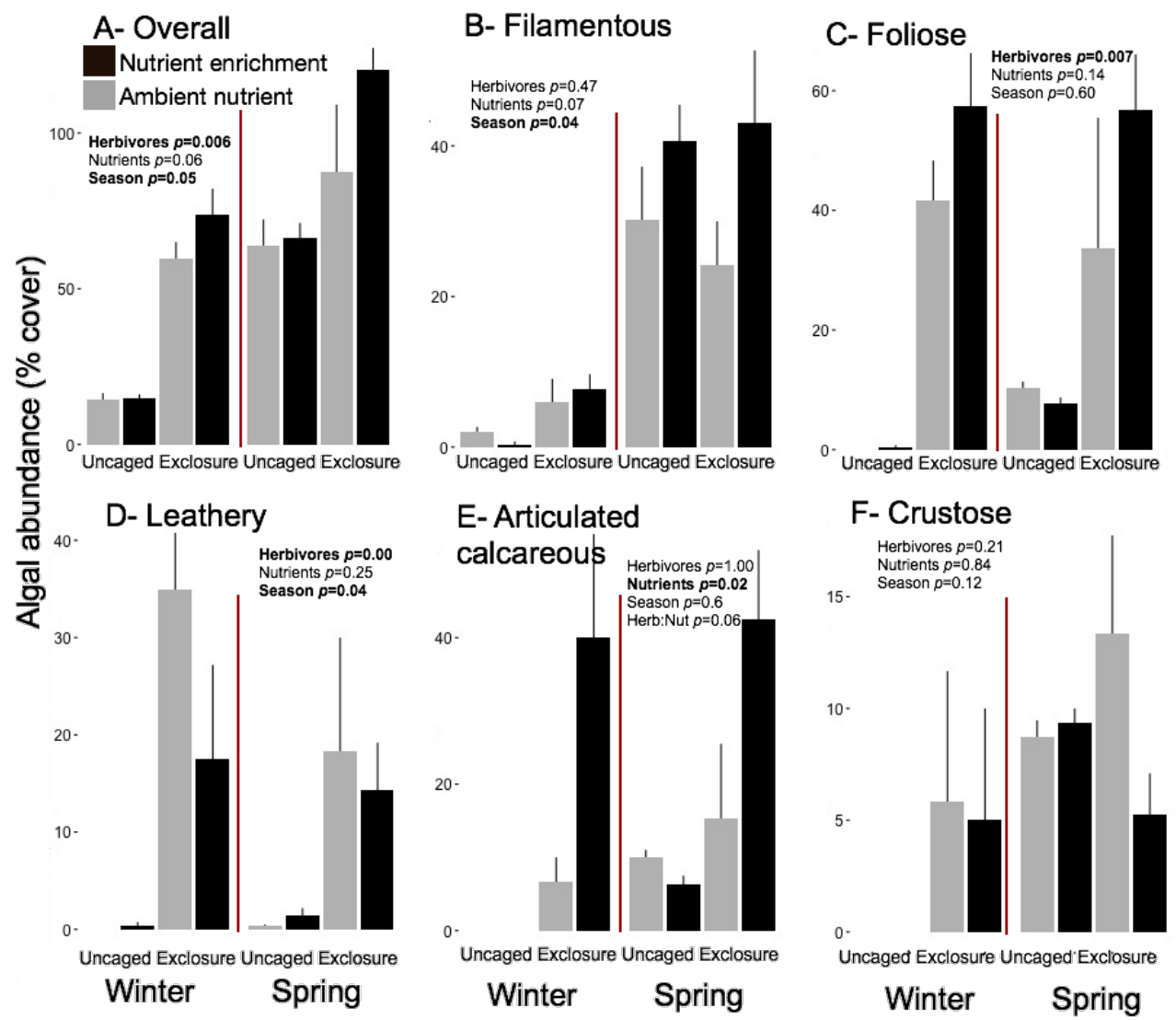

754 Figure 5. Abundance of macroalgal form-functional group on established communities by

755 treatment in winter and spring. Bars represent means \pm SEM. Probability values $(p)$ come from

756 Split plot ANOVA of main treatment effects and significant interactions. Red lines help to

757 distinguish bars across seasons with right side for spring and left side for winter

758

759

760

761 
765

766

767

768

769

770

771

772

773

774

775 